\title{
Effect of Entrapped Preceding Rice Crop Herbicide Oxadiargyl on Growth and Yield of Succeeding Bhendi
}

\author{
N. Bommayasamy ${ }^{1 *}$, C. R. Chinnamuthu ${ }^{1}$, N. S. Venkataraman ${ }^{1}$, \\ K. Balakrishnan ${ }^{2}$, A. Rathinasamy ${ }^{3}$ and B. Gangaiah ${ }^{4}$ \\ ${ }^{1}$ Department of Agronomy, AC \& RI, Madurai-625 104, Tamil Nadu, India \\ ${ }^{2}$ Unit of Crop Physiology, Dept. of Seed Science \& Technology, AC \& RI, Madurai-625 104, \\ Tamil Nadu, India \\ ${ }^{3}$ Department of Soils and Environment, AC \& RI, Madurai-625 104, Tamil Nadu, India \\ ${ }^{4}$ Division of NRM, ICAR-Central Island Agricultural Research Institute, \\ Port Blair-744101, India \\ *Corresponding author
}

\section{A B S T R A C T}

Keywords

Bhendi, rice, herbicide, residue, weeds

Article Info

Accepted:

18 May 2018

Available Online:

10 June 2018
A field experiment was conducted to evaluate the effect of preceding rice crop herbicide residue on growth and yield of succeeding bhendi crop at the Agricultural College and Research Institute, Madurai during Rabi, 2017. The experiment was laid out for the preceding transplanted rice crop in kharif 2017, which consists of eight treatments with three replications. The residual effect of herbicide applied to rice on the bhendi crop recorded lower weed density throughout the crop growth period lead thicker stem compared to weedy check. There was an appreciable difference in total density and dry weight of weeds in bhendi at 20 and 40 days after sowing among the weed control practices. Rooting depth of the bhendi crop is positively correlated with plant height, root dry weight and root thickness. Significantly higher fresh fruit yield of 3.70, 1.57 and 1.32 times were recorded in plots applied with butachlor at $1.25 \mathrm{~kg} \mathrm{ha}^{-1}$ on 3 DAT $f b$ hand weeding on 40 DAT, oxadiargyl loaded in zeolite on 3 DAT $\left(\mathrm{T}_{2}\right)$, oxadiargyl encapsulated with water soluble polymer on $3 \mathrm{DAT}\left(\mathrm{T}_{4}\right)$ to previous rice crop, respectively.

\section{Introduction}

Bhendi or okra (Abelmoschus esculentus L. Moench) is an important vegetable which are used as fresh, canned or dried and ground as powder. The seeds contain approximately 21 , 14 and 5 per cent of protein, lipids and ash respectively (Iyagba et al., 2012). Adaptability to a wide range of soil and climatic conditions and suitability for year-round cultivation has made bhendi as a popular vegetable crop, especially in the semi-arid regions of the world. India is the leading country in the world with the production of 5.7 million tonnes from over 0.50 million ha area with a productivity of 11.9 tonnes per hectare (NHB, 2015-16). The crop can't tolerate weed competition because of its slow initial growth rate and canopy coverage for effective shading (Carlson and Kirby 2005). Weeds are the 
silent robbers of natural resources like nutrient, moisture, sun light and space, it also act as alternate host for pests and disease causing organisms; which diminish the crop quality and yield. Because of more diverse weed flora of grasses, sedges and broad-leaf weeds which reduce crop yield varied from 40 to 80 per cent depending on the type of flora, their intensity and stages (Patel et al., 2004; Jalendhar et al., 2016). Recently population pressure has forced to enhance the vegetable production with limited available resources.

Intensification of agriculture has amble scope to increase vegetable production in rice fallow system, because of preparatory cultivation is more arduous and requires conducive condition, time consuming, more expensive of cost and drudgery. Weeding operation is also difficult and uneconomical practice in this system because of dense stubbles and nonavailability of labour in time and application of either pre-sowing or pre-emergence herbicides is also difficult due to lack of field preparation and limited period of their application (Sasikala et al., 2014). Keeping this in view, the present study was carried out to evaluate the effect of preceding rice herbicide residue on weeds and growth and yield of succeeding bhendi crop.

\section{Materials and Methods}

A field experiment was conducted to evaluate the effect preceding rice herbicide residue on the growth and yield of succeeding bhendi at Central Farm, Department of Farm Management, Agricultural College and Research Institute, Madurai during Rabi, 2017. The farm is geographically located at $9^{\circ}$ 54' $\mathrm{N}$ latitude and $78^{\circ} 80^{\prime} \mathrm{E}$ longitude at an altitude of $147 \mathrm{~m}$ above mean sea level. The soil of the experimental field was sandy clay loam in texture, with low, medium and medium in available $\mathrm{N}, \mathrm{P}$ and $\mathrm{K}$ respectively. The experiment was laid out to the preceding rice crop which comprises eight treatments with three replications. The weed control treatments viz., pre-emergence application of oxadiargyl loaded with biochar at 3 DAT $\left(\mathrm{T}_{1}\right)$, oxadiargyl loaded with zeolite at 3 DAT $\left(\mathrm{T}_{2}\right)$, encapsulated oxadiargyl with starch at 3 DAT $\left(\mathrm{T}_{3}\right)$, encapsulated oxadiargyl with water soluble polymer on 3 DAT $\left(\mathrm{T}_{4}\right)$, oxadiargyl at $100 \mathrm{~g}$ ha- 1 at 3 DAT $\left(\mathrm{T}_{5}\right)$. These treatments were compared with butachlor at $1.25 \mathrm{~kg}$ ha-1 on 3 DAT fb Hand weeding on 40 DAT $\left(\mathrm{T}_{6}\right)$, weed free check $\left(\mathrm{T}_{7}\right)$ and weedy check $\left(\mathrm{T}_{8}\right)$. In the succeeding bhendi crop slight modification in treatment $\mathrm{T}_{6}$-hand weeding twice at 20 and 40 DAS was included.

Bhendi hybrid CO-4 with 110 days duration was used as a test variety. The crop was fertilized with the recommended dose of 200:100:100 kg NPK ha ${ }^{-1}$ as source of urea, single super phosphate and muriate of potash. Nitrogen applied as three equal splits, one third of nitrogen, full dose of phosphorus and fifty per cent of potash was applied as basal while remaining the remaining nitrogen was applied in two splits on 30 and 60 DAS. The balance fifty per cent of potash was applied on 30 DAS. Bhendi hybrid CO-4 with seed the rate of $5 \mathrm{~kg} \mathrm{ha}^{-1}$ was used. The seeds were dibbled at the rate of two seeds hil ${ }^{1-1}$ in the rice stubbles with a spacing of $45 \times 30 \mathrm{~cm}$ during the first week of January. Gap filling and thinning was done on 10 DAS and leaving a single healthy plant hill ${ }^{-1}$. Crop was irrigated immediately after sowing and life irrigation was given on three days after sowing and subsequent irrigations were given as and when crop required. Need based plant protection measures were given whenever pest incidences are more than economic threshold level. The data was statistically analyzed by following the method of Gomez and Gomez (2010). The data pertaining to weeds were transformed to square root of $\mathrm{x}+2$ and analysed as suggested by Snedecor and Cochran (1967). 


\section{Results and Discussion}

\section{Weed characters}

The weed flora of the experimental fields consisted of grasses, sedges and broad leaved weeds. Echinochloa colonum, Leptochloa chinensis, Panicum flavidum, Cynodon dectylon in grasses, Cyperus rotundus, Fimbristylis miliacea, Cyperus difformis in sedges; Eclipta alba, Ammannia baccifera, Convolvulus arvensis, Phyllanthus maderaspatensis, Phyllanthus niruri, Trianthema portulacastrum, Boerhavia diffusa, Cleome viscosa in broad leaved weeds were the dominant weed species observed in the experimental field.

There was an appreciable difference in total weed density and total weed dry weight at 20 and 40 DAS due to weed management practices (Table 1). Application of butachlor at $1.25 \mathrm{~kg} \mathrm{ha}^{-1}$ on 3 DAT $f b$ hand weeding on 40 DAT (preceding rice crop) + hand weeding twice at 20 and 40 DAS recorded significantly lower weed density $\left(\mathrm{T}_{6}\right)$. The next best treatment was oxadiargyl loaded with zeolite on 3 DAT $\left(\mathrm{T}_{2}\right)$ which was on par with oxadiargyl encapsulated with water soluble polymer on 3 DAT $\left(T_{4}\right)$. The same trend was observed in total weed dry weight at 20 DAS.

However, at 40 DAS, the lowest weed dry weight of $37.61 \mathrm{~g} \mathrm{~m}^{-2}$ was registered in residual effect of preceding crop applied with butachlor at $1.25 \mathrm{~kg} \mathrm{ha}^{-1} \mathrm{fb}$ hand weeding + hand weeding twice at 20 and 40 DAS. This is conformity with the results reported by Jalendhar et al., (2017). The easy identification and effective removal of germinated weeds in hand weeding treatment imposed to the preceding rice crop considerably reduced the weed seed bank built up could be positively attributed to the lower total weed density and total weed dry weight in the succeeding bhendi crop. The residual effect of oxadiargyl encapsulated with water soluble polymer on 3 DAT $\left(\mathrm{T}_{4}\right)$ was recorded total weed dry weight of $45.48 \mathrm{~g} \mathrm{~m}^{-2}$ which was comparable with oxadiargyl loaded with zeolite on 3 DAT $\left(\mathrm{T}_{2}\right)\left(50.56 \mathrm{~g} \mathrm{~m}^{-2}\right)$ and oxadiargyl loaded in the biochar on 3 DAT $\left(T_{3}\right)$. This is might be due to the slow release of entrapped herbicide reduced the herbicide movement within the soil column and keeping the sizable portion of the active ingredient in the upper soil layer over a long period. This may lead to improved weed control efficiency and reduce the frequencies of herbicide application. The results are conformity with the earlier findings reported by Shirvani et al., (2014).

\section{Growth characters}

Weed control treatments significantly influenced the growth characters viz., plant height, root length, root volume and root dry weight, stem girth (Table 2). The residual effect of herbicide applied to previous rice crop has contained weed emergence throughout the crop growth period leads thicker stem compared to weedy check (Olaniyan et al., 2015). The structure of crop changed with weed control treatment, both above and below ground. All weed control treatments differed significantly from each other. Plant height of bhendi was varied from 43.4 to $106.2 \mathrm{~cm}$. The shorter root length of $17.9 \mathrm{~cm}$ was noticed in weedy check $\left(\mathrm{T}_{8}\right)$. Rooting depth positively correlated with plant height, root dry weight and root thickness. The root volume varied from 10.7 to $39.3 \mathrm{~cm}^{3}$ hill $^{-}$ ${ }^{1}$. Butachlor at $1.25 \mathrm{~kg} \mathrm{ha}^{-1}$ applied on 3 DAT $f b$ hand weeding on $40 \mathrm{DAT}+$ hand weeding twice at 20 and 40 DAS recorded significantly higher root volume and root dry weight of $30.3 \mathrm{~cm}^{3}$ hill $^{-1}$ and $4.39 \mathrm{~g}$ plant $^{-1}$ respectively. This was followed by oxadiargyl loading with zeolite on 3 DAT $\left(\mathrm{T}_{2}\right)$, and oxadiargyl encapsulated with water soluble polymer on 3 $\operatorname{DAT}\left(\mathrm{T}_{4}\right)$. 
Table.1 Effect of rice herbicide residue on total weed density (No. $\mathrm{m}^{-2}$ ) and total weed dry weight $\left(\mathrm{g} \mathrm{m}^{-2}\right)$ of succeeding bhendi crop

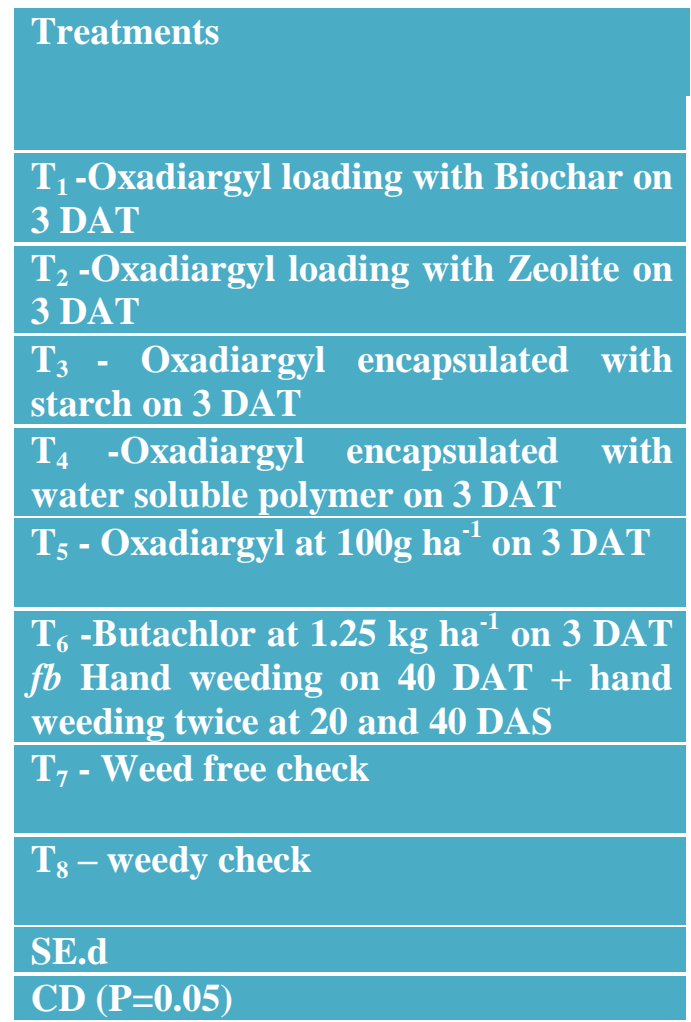

\begin{tabular}{|c|c|c|c|}
\hline $\begin{array}{c}\text { Total weed density } \\
\left(\text { No. } \text { m }^{-2}\right)\end{array}$ & \multicolumn{2}{|c|}{$\begin{array}{c}\text { Total weed dry weight } \\
\left(\mathrm{g} \mathrm{m}^{-2}\right)\end{array}$} \\
\hline 20 DAT & 40 DAT & 20 DAT & 40 DAT \\
\hline 6.66 & 12.10 & 5.44 & 7.45 \\
$(42.33)$ & $(144.67)$ & $(27.61)$ & $(53.65)$ \\
\hline 5.74 & 10.75 & 4.75 & 7.25 \\
$(31.00)$ & $(113.67)$ & $(20.57)$ & $(50.56)$ \\
\hline 8.37 & 13.08 & 5.14 & 7.69 \\
$(68.00)$ & $(169.33)$ & $(24.55)$ & $(57.29)$ \\
\hline 6.50 & 11.16 & 5.12 & 6.89 \\
$(40.33)$ & $(122.67)$ & $(24.23)$ & $(45.48)$ \\
\hline 9.73 & 13.10 & 6.47 & 8.13 \\
$(92.67)$ & $(170.00)$ & $(39.87)$ & $(65.01)$ \\
\hline 4.82 & 8.77 & 4.90 & 6.26 \\
$(21.33)$ & $(75.67)$ & $(22.40)$ & $(37.61)$ \\
\hline & & & \\
\hline 1.41 & 1.41 & 1.41 & 1.41 \\
$(0.00)$ & $(0.00)$ & $(0.00)$ & $(0.00)$ \\
\hline 11.99 & 16.41 & 10.07 & 11.71 \\
$(142.33)$ & $(268.00)$ & $(99.54)$ & $(135.30)$ \\
\hline 0.33 & 0.56 & 0.32 & 0.45 \\
\hline 0.70 & 1.20 & 0.68 & 0.97 \\
\hline
\end{tabular}

Table. 2 Effect of rice herbicide residue on plant height, root characteristics and stem girth at harvesting stage of succeeding bhendi crop

\begin{tabular}{|c|}
\hline Treatment \\
\hline $\begin{array}{l}T_{1} \text {-Oxadiargyl loading with Biochar on } 3 \\
\text { DAT }\end{array}$ \\
\hline $\mathrm{T}_{2}$-Oxadiargyl loading with Zeolite on 3 DAT \\
\hline $\begin{array}{l}\text { T }_{3} \text { - Oxadiargyl encapsulated with starch on } 3 \\
\text { DAT }\end{array}$ \\
\hline $\begin{array}{l}\mathrm{T}_{4} \text {-Oxadiargyl encapsulated with water } \\
\text { soluble polymer on } 3 \text { DAT }\end{array}$ \\
\hline $\mathrm{T}_{5}$ - Oxadiargyl at $100 \mathrm{~g} \mathrm{ha}^{-1}$ on 3 DAT \\
\hline $\begin{array}{l}\mathrm{T}_{6}-\text { Butachlor at } 1.25 \mathrm{~kg} \mathrm{ha}^{-1} \text { on } 3 \mathrm{DAT} \mathrm{fb} \\
\text { Hand weeding on } 40 \mathrm{DAT}+\text { hand weeding } \\
\text { twice at } 20 \text { and } 40 \mathrm{DAS}\end{array}$ \\
\hline$T_{7}-$ Weed free check \\
\hline $\mathrm{T}_{8}$ - weedy check \\
\hline SE.d \\
\hline $\mathrm{CD}(\mathrm{P}=0.05)$ \\
\hline
\end{tabular}

\begin{tabular}{|c|c|c|c|c|}
\hline \multirow{2}{*}{$\begin{array}{c}\text { Plant } \\
\text { height } \\
(\mathrm{cm})\end{array}$} & \multicolumn{3}{|c|}{ Root characteristics } & \multirow{2}{*}{$\begin{array}{l}\text { Stem } \\
\text { girth } \\
(\mathrm{cm})\end{array}$} \\
\hline & $\begin{array}{l}\text { Root } \\
\text { length } \\
(\mathrm{cm})\end{array}$ & $\begin{array}{l}\text { Root volume } \\
\left(\mathrm{cm}^{3} \text { plant }^{-1}\right)\end{array}$ & $\begin{array}{l}\text { Root dry } \\
\text { weight } \\
\left(\text { g plant }^{-1}\right)\end{array}$ & \\
\hline 66.2 & 23.5 & 13.5 & 3.66 & 4.08 \\
\hline 67.8 & 24.7 & 15.4 & 3.71 & 4.56 \\
\hline 63.6 & 23.2 & 10.8 & 2.75 & 4.09 \\
\hline 69.9 & 21.3 & 18.3 & 3.94 & 3.97 \\
\hline 56.4 & 19.3 & 10.7 & 2.60 & 4.20 \\
\hline 92.7 & 24.6 & 30.3 & 4.39 & 4.93 \\
\hline 106.2 & 27.9 & 39.3 & 5.82 & 5.62 \\
\hline 43.4 & 17.9 & 10.7 & 2.53 & 3.59 \\
\hline 4.94 & 1.01 & 0.99 & 0.15 & 0.21 \\
\hline 10.57 & 2.16 & 2.12 & 0.33 & 0.44 \\
\hline
\end{tabular}


Table.3 Effect of rice herbicide residue on fruit weight ( $\mathrm{g}$ fruit $\left.{ }^{-1}\right)$, fruit yield $\left(\mathrm{t} \mathrm{ha}^{-1}\right)$ and harvest index of succeeding bhendi crop

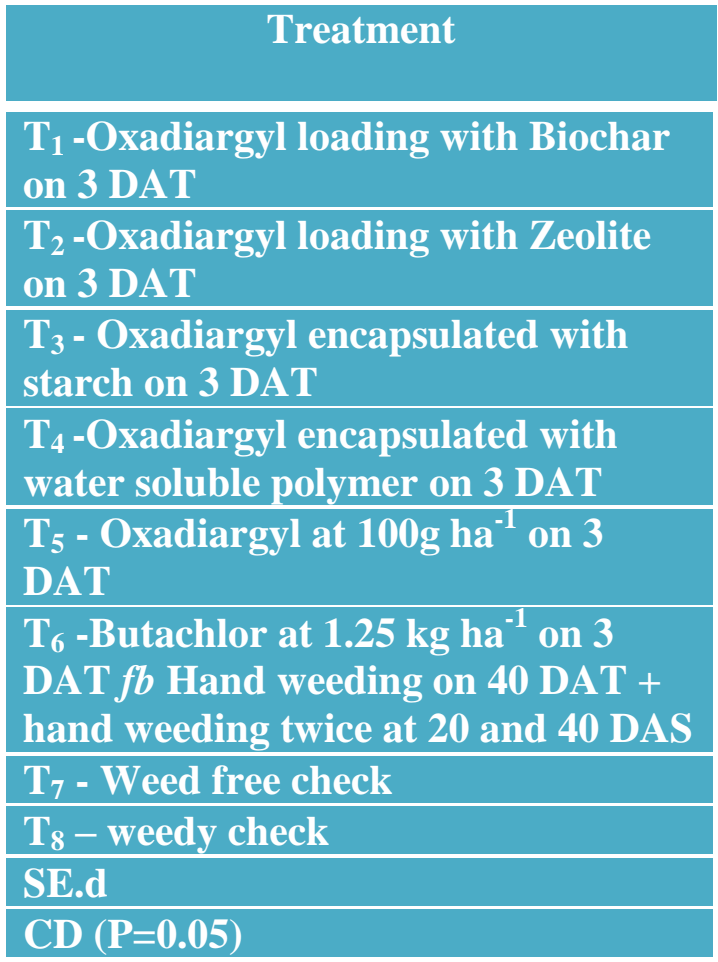

The increased root volume was due to the increased in root number and root thickness (Sinha et al., 2000). Stem girth of 4.93 and $4.56 \mathrm{~g} \mathrm{plant}^{-1}$ was observed in butachlor at $1.25 \mathrm{~kg} \mathrm{ha}^{-1}$ on 3 DAT $f b$ hand weeding on 40 DAT + hand weeding twice at 20 and 40 DAS and oxadiargyl loading with zeolite on 3 DAT $\left(\mathrm{T}_{2}\right)$ respectively, both the treatments were comparable with each other. This might be due to more amounts of nutrient and other resource was effectively utilized by crop owing to lower weed dry matter production. The lowest root volume, root dry weight and stem girth showed in weedy check $\left(\mathrm{T}_{8}\right)$.

\section{Yield characters}

Individual fruit weight, fruit yield and harvest index was significantly superior in weed free check $\left(\mathrm{T}_{7}\right)$. Among the weed control treatments, butachlor at $1.25 \mathrm{~kg}$ ha 1 applied to rice crop on 3 DAT $f b$ hand weeding on 40

\begin{tabular}{|c|c|c|}
\hline $\begin{array}{c}\text { Fruit weight } \\
(\mathrm{g} \text { fruit }\end{array}$ & $\begin{array}{c}\text { Fruit yield }(\mathrm{t} \\
\left.\mathbf{h a}^{-1}\right)\end{array}$ & $\begin{array}{c}\text { Harvest } \\
\text { Index }\end{array}$ \\
\hline 20.3 & 7.55 & 0.591 \\
\hline 24.5 & 8.40 & 0.549 \\
\hline 17.4 & 7.17 & 0.596 \\
\hline 22.7 & 7.59 & 0.600 \\
\hline 16.3 & 5.97 & 0.594 \\
\hline 23.8 & 15.37 & 0.619 \\
\hline & & \\
\hline 27.5 & 24.19 & 0.650 \\
\hline 11.6 & 3.27 & 0.459 \\
\hline 0.86 & 0.56 & 0.030 \\
\hline 1.84 & 1.20 & 0.063 \\
\hline
\end{tabular}

DAT + hand weeding twice at 20 and 40 DAS has recorded higher individual fruit weight of 23.8 g. It was comparable with oxadiargyl loaded with zeolite on 3 DAT $\left(\mathrm{T}_{2}\right)$. The lowest fruit weight of $11.6 \mathrm{~g}$ was recorded in weedy check $\left(\mathrm{T}_{8}\right)$. This may be attributed due to the results of unfavorable growth conditions prevailed during the crop growth period. The higher weed density and weed dry weight negatively influenced the crop leaf area results in reduced source sink relationship. Significantly higher fruit yield of 3.70, 1.57 and 1.32 times were recorded under butachlor at $1.25 \mathrm{~kg} \mathrm{ha}^{-1} \mathrm{fb}$ hand weeding on 40 DAT + hand weeding twice at 20 and 40 DAS, oxadiargyl loaded with zeolite on 3 DAT $\left(\mathrm{T}_{2}\right)$, oxadiargyl encapsulated with water soluble polymer on 3 DAT $\left(\mathrm{T}_{4}\right)$ compared to weedy check. The higher fruit yield may be attributed due to less competition of weeds and decreased density that helped in enhances the yield attributes. 
These findings were supported by Kumar et al., (2011) and Sharma and Patel (2011). Weed free check exerted significantly higher harvest index of 0.650 which was comparable with butachlor at $1.25 \mathrm{~kg} \mathrm{ha}^{-1}$ on 3 DAT $\mathrm{fb}$ hand weeding on 40 DAT + hand weeding twice at 20 and 40 DAS, oxadiargyl encapsulated with water soluble polymer on 3 DAT $\left(\mathrm{T}_{4}\right)$, oxadiargyl loading with biochar on 3 DAT $\left(T_{1}\right)$ which was comparable with each other. This is mainly due to lower crop weed competition which facilitates higher uptake of nutrients and other resources resulting on higher yield attributes. The lowest yield character of individual fruit weight, fruit yield and harvest index were registered in weedy check $\left(\mathrm{T}_{8}\right)$.

\section{References}

Iyagba, A.G., Onuegbu, B.A., Ibe, A.E. 2012. Growth and yield response of okra (Abelmoschus esculentus (L.) Moench) varieties to weed interference in SouthEastern Nigeria. Global Journal of Science Frontier Research, 12(1):23-31.

Jalendhar, G., Chandra Shekar Reddy K., Srinivas, A. and Manohar Rao, A. 2016. Effect of integrated weed management practices on growth, yield and it's attributes in okra (Abelmoschus esculentus (L.) Moench) cv. Arka Anamika. International Journal of Science and Nature. 7(1): 165-167.

Kumar, A., Sharma, B., Parshotam Sharma, K., Kumar, R. and Venna, V. 2009. Integrated weed management strategies in okra under irrigated subtropical conditions of Jammu and Kashmir. Indian Journal of Weed Science, 41(3\&4): 49-51.

Kumar, S., Angiras, N.N., Shrama, P. and Rana, S.S. 2011. Integrated weed management in okra (Abelmoschus esculentus L. Moench.) under mid-hill condition of Himachal Pradesh.
Himachal. Journal of Agricultural Research, 37(1): 10-16.

NHB-2015-16, National Horticulture Board, Ministry of Agriculture and Farmers Welfare, Govt. of India Gurugram, Haryana

Olaniyan, A.B., Olaniyi O.W. and Akintola, M.S. 2015. Morpho-physiological and yield response of okra fertilizer application and weed control. In: Conference on International Research on Food Security (Eric Tielkes, Ed.), Pp.117. Berlin, Germany.

Pandey, V.K and Mishra, A.C. 2013. Weed management technology in okra. In: National Symposium on Abiotic and Biotic Stress Management in Vegetable Crops. North America, March.

Patel, R.B., Patel, B.D., Meisuriya, M.I., and Patel, V.J. 2004. Effect of methods of herbicide application on weeds and okra (Abelmoschus esculentus (L.) Moench). Indian Journal of Weed Science, 36(3\&4): 304-305.

Patel, T.U., Zinzala, M.J., Patel, D.D., Patel, H.H. and Italiya, A.P. 2017. Weed management influence on weed dynamics and yield of summer lady's finger. Indian Journal of Weed Science, 49(3): 263-265, 2017.

Sasikala, K., Ramachandra Boopathi, SNM and Pashok. 2014. Evaluation of methods of sowing and post emergence herbicides for efficient weed control in zero till sown rice fallow black gram Vigna mungo L. International Journal of Farm Sciences, 4(1): 81-91.

Sharma, S. and Patel, B.D. 2011. Weed management in okra grown in Kharif season under middle Gujarat condition. Indian Journal of Weed Science, 43(3\&4): 226-227.

Shirvani, M., Farajollahi, E., Bakhtiari,S. and Ogunseitan, O.A. 2014. Monilut and efficiency of 2, 4- D herbicide from slow release delivery systems based on 
organo-zeolite and organo bentonite complexes, Journal of Environmental Science and Health, Part B: Pesticides, Food Contaminants and Agricultural Wastes, 49(4):255-262.

Shivalingappa S, Eugenia P, Bangi S and Sattigeri U. 2014. Effect of herbicides on weed control efficiency and yield attributes in brinjal. Journal of Agriculture and Veterinary Science, 7(6): 59-65.
Singh, M., Prabhukumar, S. and Sairam, C.V. 2010. Integrated weed management in okra (Abelmoschus esculentus L. Moench.). Annals of Protection Science, 18(2): 481-483.

Sinha, P.K., Prasad, K. and Mishra, G.N. 2000. Studies on root characters related to drought resistance and their association in selected upland rice genotypes. Oryza, 37(1): 29-31.

\section{How to cite this article:}

Bommayasamy N., C. R. Chinnamuthu, N. S. Venkataraman, K. Balakrishnan, A. Rathinasamy and Gangaiah B. 2018. Effect of Entrapped Preceding Rice Crop Herbicide Oxadiargyl on Growth and Yield of Succeeding Bhendi. Int.J.Curr.Microbiol.App.Sci. 7(06): 1915-1921. doi: https://doi.org/10.20546/ijcmas.2018.706.227 